\title{
PRECONCEITO LINGUÍSTICO EM COMENTÁRIOS DE MEMES
}

\author{
Linguistic Prejudice on Meme Comments
}

\author{
Mayara do Rocio Lima GASPAR \\ Universidade Estadual de Ponta Grossa \\ mayllyma@gmail.com \\ http://orcid.org/0000-0002-2175-2987 \\ Márcia Cristina do CARMO \\ Universidade Estadual de Ponta Grossa \\ mccarmo@uepg.br \\ http://orcid.org/0000-0003-0546-7622
}

RESUMO: Este artigo analisa o preconceito linguístico em comentários de memes em uma página presente na rede social Facebook. Como fundamentação teórica, segue-se a Teoria da Variação e Mudança Linguística (LABOV, 2008 [1972]) e discute-se a noção de preconceito linguístico a partir de trabalhos de Bagno (2002; 2007; 2009a; 2009b; 2017), Calvet (2002), dentre outros, incluindo sua presença nos ciberespaços (BEZERRA; PIMENTEL, 2016; RADTKE, 2017; ROMANO; PEREIRA, 2017). Ressaltamos a importância das orientações dos Parâmetros Curriculares Nacionais (BRASIL, 1998; 2000) no que tange a essa temática para o ensino de língua portuguesa. Por meio da análise de 100 dados, evidenciamos o preconceito linguístico de forma mais evidente em 44 comentários, mesmo sendo a página voltada a professores e profissionais da área da educação. A partir desta pesquisa, explicitamos a relevância do conteúdo de variação e mudança linguística na formação inicial e continuada de professores de língua portuguesa, a fim de combater o preconceito linguístico, muitas vezes pautado em um ensino tradicional de gramática normativa. PALAVRAS-CHAVE: Comentários de memes; Formação de professores; Preconceito linguístico; Variação e mudança linguística.

ABSTRACT: This paper analyses linguistic prejudice on meme comments in a page on Facebook. As the theoretical background, this work follows the Linguistic Variation and Change Theory (LABOV, 2008 [1972]) and discusses the concept of linguistic prejudice from the works of Bagno (2002; 2007; 2009a; 2009b; 2017), Calvet (2002), among others, including its presence on cyberspaces (BEZERRA; PIMENTEL, 2016; RADTKE, 2017; ROMANO; PEREIRA, 2017). We highlight the relevance of the guidelines of the National Curricular Parameters (BRA- 
SIL, 1998; 2000) with respect to this theme for the teaching of Portuguese. Through the analysis of 100 data, we evince linguistic prejudice more evidently on 44 comments, even though the page is aimed at teachers and professionals of education. From this research, we highlight the relevance of the content of linguistic variation and change in the initial and continuing education of teachers, in order to combat linguistic prejudice, often rested on a traditional teaching of normative grammar. KEYWORDS: Linguistic prejudice; Linguistic variation and change; Meme comments; Teacher training.

\section{INTRODUÇÃO}

Este artigo $^{1}$ analisa o preconceito linguístico em comentários de memes publicados na rede social Facebook, em determinada página voltada a docentes e profissionais da educação. Esses comentários podem carregar marcas de preconceito linguístico referentes à diversidade linguística no que tange tanto à modalidade falada quanto escrita do Português Brasileiro (doravante, PB).

Apesar da existência de diversas investigações sobre preconceito linguístico em gêneros textuais/discursivos variados, inclusive em comentários em sites de notícias (ROMANO; PEREIRA, 2017), ainda são escassos os trabalhos que abordam o preconceito linguístico em comentários de memes.

A partir de uma perspectiva discursiva, Radtke (2017), por exemplo, analisa ocorrências de preconceito linguístico em seis publicações retiradas da página "Português da Depressão", do Facebook, considerando postagens, comentários e compartilhamentos, entre outros. Ao analisar determinados comentários, a autora afirma que "grande parte viabiliza o Discurso e se foca no discurso veiculado na publicação, inclusive fazendo uma apropriação do mesmo para fazer críticas e filiar-se a outro Discurso, o do purismo na língua portuguesa" (RADTKE, 2017, p. 70).

Nesse contexto, esta pesquisa busca testar a hipótese inicial de haver preconceito linguístico em comentários de memes, explicitando desconhecimento quanto a língua(gem) e (socio)linguística e sendo pautados pela gramática normativa, difundida no ensino tradicional de língua portuguesa.

Como fundamentação teórica, seguimos os pressupostos da Sociolinguística ou Teoria da Variação e Mudança Linguística (LABOV, 2008 [1972]), além de autores como

\footnotetext{
${ }^{1}$ Este artigo é fruto de um Trabalho de Conclusão de Curso (TCC), intitulado "Dói na alma": o preconceito linguístico em comentários de memes, defendido pela primeira autora na UEPG em 2019, sob a orientação da segunda autora.
} 
Bagno (2002; 2007; 2009a; 2009b; 2017), Calvet (2002), dentre outros, que explicam o preconceito linguístico. Tendo em vista o público-alvo da página, apresentamos, também, ações orientadas pelos Parâmetros Curriculares Nacionais (PCNs) para o ensino de língua materna no que diz respeito ao preconceito linguístico (BRASIL, 1998; 2000).

Este artigo está estruturado da seguinte forma: inicialmente, é apresentada a fundamentação teórica em relação: (i) à Teoria da Variação e Mudança Linguística; (ii) ao preconceito linguístico; (iii) à sua presença na modalidade escrita e nos ciberespaços; (iv) à discussão sobre preconceito linguístico nos PCNs. Em seguida, são arrolados o material e o método utilizados nesta investigação. Posteriormente, é exposta a análise dos dados, seguida pelas considerações finais, pelas referências bibliográficas e pelo anexo.

\section{TEORIA DA VARIAÇÃO E MUDANÇA LINGUÍSTICA}

Este artigo baseia-se teoricamente na Sociolinguística ou Teoria da Variação e Mudança Linguística, modelo proposto pelo linguista norte-americano William Labov. Essa corrente teórica tem como pressuposto a sistematização das variações linguísticas e da língua falada, fazendo associação das relações entre língua e sociedade. Nessa perspectiva, Labov (2008 [1972]) defende a língua como instrumento variável, considerando sua evolução por meio de três etapas. Considera que a mudança se inicia pela variação, que pode ser observada em discursos utilizados pelos falantes e, depois, propaga-se, sendo, então, adotada pelos falantes que outrora se opunham à variante. Por fim, realiza-se e alcança-se regularidade, passando a ser adotada por todos os falantes.

Em toda comunidade em que há falantes da língua, também haverá variação das formas linguísticas, que são chamadas de variantes. Estas correspondem, segundo Tarallo (2003), às várias maneiras de se transmitir a mesma mensagem em um mesmo contexto, com um mesmo valor de verdade. Ao conjunto de variantes, chamamos de variável linguística. Um exemplo de variação linguística no PB consiste na marcação do plural no sintagma nominal ( $\mathrm{SN}$ ), que apresenta duas variantes linguísticas: a presença de (s), como em "as meninas", e sua ausência, representada por $\varnothing$, como em "as menina (TARALLO, 2003).

A variação pode ocorrer nos diferentes níveis linguísticos: fonético-fonológico, morfológico, sintático, semântico, etc., bem como em suas interfaces. Além da concordância de plural no SN, citada por Tarallo (2003), podemos mencionar, como processos variáveis recorrentes no $\mathrm{PB}$, por exemplo: alçamento vocálico, rotacismo, monotongação, ditongação diante de /S/ em coda silábica, estratégias de relativização, 
variação dos pronomes oblíquos "me" e "mim" na posição de sujeito, dentre outros. Esses fenômenos serão apresentados no decorrer da análise dos dados deste artigo, de modo a explicitar que o preconceito linguístico em comentários de memes evidencia, muitas vezes, falta de conhecimento científico sobre processos variáveis como os aqui citados.

Tarallo (2003) explicita que as variantes costumam estar em uma relação de concorrência entre padrão e não-padrão, conservadora e inovadora, prestigiada e estigmatizada. Todavia, costuma ser evidenciada e prestigiada a variante padrão e conservadora, ao passo que a variante não-padrão e inovadora costuma ser estigmatizada.

Segundo o linguista, é perceptível o acesso de índices mais acentuados da variante de prestígio pelos grupos sociais de níveis mais altos. Por sua vez, a variante estigmatizada costuma ser mais utilizada pelos grupos sociais com níveis socioeconômicos mais baixos. Mesmo que a variante padrão não seja a mais usada em uma comunidade, ela é vista, de modo geral, como aquela de prestígio; enquanto a não padrão, ainda que mais comum a grande parcela da sociedade, é desprestigiada e vista negativamente. Essa atitude quanto a variantes estigmatizadas é apresentada na seção seguinte.

\section{PRECONCEITO LINGUÍSTICO}

Como visto anteriormente, língua e sociedade são fatores correlacionados às variações linguísticas existentes. Sendo assim, é imprescindível o estudo da (socio) linguística para a reflexão sobre fenômenos linguísticos variáveis que constituem o PB. Faz-se, portanto, necessária a compreensão da variação linguística para que, assim, seja reduzida a incidência de discriminação de variedades e variantes linguísticas, ato denominado preconceito linguístico.

O preconceito linguístico está inserido na sociedade pela propagação de informações equivocadas sobre a língua e por falta de conhecimento científico (socio) linguístico, concebendo a língua somente sob a ótica de uma gramática normativa inflexível.

A partir do conhecimento científico sobre processos variáveis do $\mathrm{PB}$, destacamos, como o faz Geraldi (1997), a importância (i) da valorização das variedades linguísticas do PB como parte da nossa cultura e (ii) da adequação às diversas variedades existentes, posto que:

As variedades não são erros, mas diferenças. Não existe erro linguístico. O que há são inadequações de linguagem, que consistem não no uso de uma variedade em vez de outra, mas no uso de uma variedade em vez 
de outra numa situação em que as regras sociais não abonam aquela forma de fala (GERALDI, 1997, p. 52).

Apesar da evolução histórica, o preconceito linguístico ainda está impregnado em nossa cultura e geralmente é constatado, segundo Calvet (2002), por meio de estereótipos criados por falantes que se situam em altos níveis da escala socioeconômica e menosprezam quaisquer variações existentes na língua, como os dialetos (que são variedades geográficas), concebidos pelos usuários das classes maioritárias de forma pejorativa (CALVET, 2002). Ainda se mantém uma ideia equivocada de que a língua deva ser "pura" e de que essa norma "estereotipada" deva ser vista como correta, considerando "errados" outros sotaques ou variedades.

De acordo com os pressupostos destacados anteriormente, Bagno (2009a) atesta que o preconceito linguístico tem suas origens nas camadas mais privilegiadas em relação às demais classes sociais.

\begin{abstract}
Os brasileiros urbanos letrados não só discriminam o modo de falar de seus companheiros analfabetos, semianalfabetos, pobres e excluídos, como também discriminam o próprio modo de falar, as suas próprias variedades linguísticas (BAGNO, 2009a, p. 21).
\end{abstract}

Dessa forma, Bagno (2009a; 2017) afirma que o preconceito linguístico se exerce, no Brasil, em duas direções: (i) de dentro das camadas sociais privilegiadas para fora, contra os falantes de camadas menos abastadas socioeconomicamente; e (ii) de dentro das camadas sociais privilegiadas para seu próprio redor, contra seus próprios membros.

Calvet (2002) comprova esse fato ao discorrer sobre uma pesquisa realizada por Peter Trudgill na Grã Bretanha, que constatou que os falantes de duas variantes diferentes (sendo uma "prestigiada" e outra "desvalorizada") defendiam a ideia de língua "correta" ou "pura", sendo que ambos acreditavam que seu modo de falar era "correto". Entretanto, acreditavam, também, que havia outros modelos ainda mais prestigiados, o que evidencia uma "insegurança linguística" (CALVET, 2002, p. 73) por parte dos falantes.

Quanto ao preconceito linguístico em relação à modalidade escrita da língua, passamos à seção seguinte. 


\section{PRECONCEITO LINGUÍSTICO NA MODALIDADE ESCRITA: GRAFIAS NÃO-CONVENCIONAIS E O CIBERESPAÇO}

Tendo em vista a temática deste artigo, que analisa o preconceito linguístico em comentários de memes em rede social, cabe mencionar a discussão sobre preconceito e modalidade escrita. A partir do fato de a escrita seguir uma convenção ortográfica, as grafias que não seguem essa convenção também estão sujeitas ao preconceito. Segundo Bagno (2009b, p. 157, grifos do autor), a tradição prescritiva "atribui ao domínio da escrita um elemento de distinção social, que é na verdade um elemento de dominação por parte dos letrados sobre os iletrados". O autor salienta que saber ortografia não corresponde a saber língua, posto que a ortografia não é parte integrante da gramática de uma língua.

Para a discussão sobre grafias que não seguem a convenção ortográfica, destacamos as relações estabelecidas entre grafia, fonologia e variação linguística, objeto da teoria explicitada em seção anterior. Roberto (2016, p. 142) propõe que:

Pensemos nas várias pronúncias possíveis no Brasil para as palavras. Já vimos o quanto há variação. Se tivéssemos um sistema de escrita fiel à nossa fala, teríamos, consequentemente, várias escritas diferentes, uma vez que as pronúncias são diferentes nos vários lugares em que se fala a língua. O sistema seria fonético, portanto, com maior variação. [...] Uma ortografia fonêmica dá conta de representar várias pronúncias possíveis ao mesmo tempo, sendo comum a falantes de diferentes variedades sociolinguísticas da língua.

Cagliari (1995) corrobora a afirmação de que escrita não diz respeito a uma transcrição fonética da fala, o que faz com que, inevitavelmente, surjam as grafias que não seguem a convenção imposta, como em "rapaiz" (para "rapaz") e "camanh" (para “com a mãe") (CAGLIARI, 1998, p. 277)2. Por sua vez, dentre outros exemplos, Bagno (2009b) apresenta quatro possibilidades de sons para o grafema $<x>$, a saber: (i) [s], como em próximo; (ii) [ks], como em fixo; (iii) [z], como em exame; e (iv) [J], como em xícara. O mesmo ocorre no internetês, onde encontramos registros como "leiti" (para "leite"), representando a pronúncia alçada da vogal postônica final (ROBERTO, 2016), como será apresentado na análise dos dados.

\footnotetext{
${ }^{2}$ Para a prática docente em relação a grafias não-convencionais, Cagliari (1998) propõe o exercício de leitura, corroborado por Bagno (2009b, p. 162-163), que afirma que "o aprendizado da ortografia se faz pelo contato íntimo e frequente com textos bem escritos, e não com regras mal elaboradas ou com exercícios pouco esclarecedores".
} 
Atualmente, um relativamente novo ambiente que evidencia diversas relações entre o oral e o escrito (ROBERTO, 2016), servindo, também, como meio de propagação do preconceito linguístico, é o ciberespaço, onde indivíduos podem manifestar e exteriorizar esse preconceito inclusive publicamente (ROMANO; PEREIRA, 2017).

Romano e Pereira (2017) ressaltam que o preconceito linguístico no ciberespaço também tem suas raízes pautadas no preconceito social. A partir de uma página da Internet que, segundo os autores, trata da língua portuguesa, evidenciam que esse preconceito atinge camadas étnicas minoritárias. Observam, por exemplo, referência com intuito jocoso a uma variante supostamente utilizada por indígenas: "Feliz Dia do Índio para você que fala: pra mim fazer!”. Essa página, segundo Bezerra e Pimentel (2016), considera importante o normativismo linguístico, defende uma "língua padrão" baseada em concepções de língua e linguagem atreladas à gramática tradicional e prescritiva. Os autores também explicitam que essas visões deturpadas demonstram o pouco conhecimento da variação do PB.

Em sua análise do preconceito linguístico em seis postagens da página "Português da Depressão" na rede social Facebook, Radtke (2017) observou, de modo geral, resultados semelhantes aos dos autores citados anteriormente, como mostra ao afirmar que:

\begin{abstract}
a associação mais recorrente deu-se especialmente pela necessidade de separação daqueles que sabem escrever e dominavam a língua tida como culta, daqueles que não dominam. O Discurso percebido foi de que se uma pessoa não sabe falar/escrever conforme a norma, ela não será capaz de ocupar uma posição social confortável. Ao contrário, ficará à margem da sociedade, pois a relação entre analfabetismo e baixo nível econômico e social é recorrente. O domínio da variação de prestígio parece servir como validação para que uns usuários minimizem outros com base no preconceito linguístico (RADTKE, 2017, p. 98).
\end{abstract}

Sobre os comentários, Radtke (2017) observou que costumam seguir a linha argumentativa da postagem e do comentário principal. Além disso, constatou que o humor contribui para a naturalização do preconceito linguístico.

Elucidamos, na seção seguinte, as orientações dos PCNs (BRASIL, 1998; 2000) no que concerne ao preconceito linguístico, tendo em vista o fato de a página analisada ser voltada, sobretudo, a professores. 


\title{
PCNS E O COMBATE AO PRECONCEITO LINGUÍSTICO
}

Reiteramos, neste trabalho, as orientações dos PCNs (BRASIL, 1998) ${ }^{3}$ aos professores de língua portuguesa de que o conhecimento linguístico e discursivo no processo de ensino-aprendizagem deva ser feito por meio da linguagem, de forma que o aluno possa construir o conhecimento a partir de suas experiências diárias fora da escola, ou seja, que possa encontrar, no ambiente escolar, espaço para interação social a partir do seu conhecimento prévio.

Esse documento pauta-se, teoricamente, nos princípios sociolinguísticos ao afirmar, por exemplo, que:

\begin{abstract}
A língua portuguesa, no Brasil, possui muitas variedades dialetais. Identificam-se geográfica e socialmente as pessoas pela forma como falam. Mas há muitos preconceitos decorrentes do valor social relativo que é atribuído aos diferentes modos de falar: é muito comum se considerarem as variedades linguísticas de menor prestígio como inferiores ou erradas (BRASIL, 1998, p. 26).
\end{abstract}

Nesse âmbito, defende a valorização da multiplicidade linguística no ensino da língua portuguesa e destaca um dos principais objetivos que deve nortear o trabalho do professor: o combate ao preconceito linguístico. Segundo o documento, isso deve ser feito com o mesmo empenho com que são combatidos os demais preconceitos sociais existentes. Também ressalta a importância da aprendizagem do aluno não só quanto à escrita, como também à oralidade, valorizando as diferentes modalidades linguísticas e suas práticas sociais.

Esse documento destaca a importância da ressignificação da noção de erro, admitindo, assim, as variedades linguísticas existentes no PB e nas comunidades em que os alunos estão inseridos, construindo reflexões efetivas sobre a linguagem. Dessa maneira, são apresentadas, ao aluno, possibilidades de domínio de novas habilidades

\footnotetext{
${ }^{3}$ Dentre os documentos oficiais, destacamos, também, a Base Nacional Comum Curricular (BNCC), documento normativo proposto como base para os ensinos Fundamental e Médio brasileiros (BRASIL, 2018). Dada sua publicação relativamente recente, partimos do pressuposto de os professores de língua portuguesa terem maior familiaridade com os PCNs (BRASIL, 1998; 2000), publicados inicialmente há mais de duas décadas. Sendo assim, como recorte teórico-metodológico - necessário para a exequibilidade de toda e qualquer pesquisa -, optamos por apresentar discussões referentes aos PCNs, deixando a BNCC para estudos futuros. Mais informações sobre este documento podem ser encontradas em: $<\mathrm{http} / / /$ basenacionalcomum.mec. gov.br/>. Acesso em: 28 fev. 2020.
} 
linguísticas, para que, a partir desses novos conhecimentos adquiridos, o aluno possa refletir sobre a linguagem ante ao contexto linguístico em que se encontra.

$\mathrm{Na}$ mesma direção, os PCNs do Ensino Médio (BRASIL, 2000) destacam a relevância da língua materna como parte do processo de construção de mundo do aluno. Nesse documento, reitera-se que a língua portuguesa deva ser um exercício que auxilie o aluno a se comunicar por meio da fala e da escrita, para que se expresse sem o receio de ser "corrigido" e, por meio da comunicação, adquira a possibilidade de ampliar seu saber linguístico, conhecendo outras possibilidades linguísticas e (des)construindo outros significados sociais.

Assim sendo, podemos afirmar que os PCNs do Ensino Fundamental (BRASIL, 1998) e Médio (BRASIL, 2000) orientam que a discriminação linguística seja combatida, propondo medidas que reduzam sua incidência no âmbito escolar e valorizando as múltiplas possibilidades linguísticas existentes na sociedade. Desse modo, ressaltam a importância, no ambiente escolar, da língua como espaço para a construção de novos saberes do aluno, ultrapassando normas gramaticais prescritivas e possibilitando, a ele, comunicar-se e construir sua própria identidade por meio da linguagem.

Feita a apresentação do arcabouço teórico que fundamenta esta pesquisa, passamos, agora, à descrição do material e métodos utilizados.

\section{MATERIAL E MÉTODOS}

Esta pesquisa, de cunho qualitativo, investiga a incidência de preconceito linguístico em comentários de memes em determinada página ${ }^{4}$ da rede social Facebook. Valemo-nos do arcabouço teórico exposto nas seções anteriores para analisar de quais formas o preconceito linguístico se faz presente, tendo, como parâmetros, alguns aspectos esperados de um professor de língua portuguesa: conhecimento sobre (socio)linguística e PCNs (BRASIL, 1998; 2000).

Em relação aos memes, são "uma unidade de transmissão cultural, ou uma unidade de imitação" (DAWKINS, 2007, p. 330). São caracterizados pelo humor que carregam em suas mensagens e podem ser de caráter religioso, humorístico, sarcástico, entre outros. Podem, também, carregar e/ou licitar mensagens preconceituosas, promovendo a disseminação de diversos preconceitos, como o linguístico, e desconsiderando a

\footnotetext{
${ }^{4}$ Por motivos éticos, será preservada a identidade da página e dos usuários que comentaram as publicações analisadas, a fim de evitar a exposição desnecessária dos indivíduos envolvidos na pesquisa, valorizando, assim, os "Códigos de Condutas" (CELANI, 2005).
} 
sistematicidade da variação e mudança linguística, objeto de estudos da Sociolinguística (LABOV, 2008 [1972]), como já apresentado neste artigo.

Ressaltamos a importância do gênero textual/discursivo meme no que tange a essa temática a partir de sua capacidade de influência, pois carrega consigo mensagens de aprovação e desaprovação, tornando-se, em vários casos, agente problematizador de questões existentes nos meios de socialização da vida real (RADTKE, 2017).

Sobre redes sociais, os autores Pinto e Junqueira (2009) afirmam corresponder a um conjunto de pessoas e organizações empresariais que se conectam, a fim de promover construções de novos grupos sociais e, por meio dessas conexões, formarem novas comunidades de conhecimento.

Quanto à rede social Facebook, esta afirma que seu objetivo é "criar comunidades e aproximar o mundo"5. A partir das plataformas disponibilizadas na rede social, é possível conectar-se com pessoas e organizações, bem como expressar-se por meio de imagens e textos que podem ser compartilhados no status do perfil do usuário e promover a conversa entre pessoas por mensagens.

Como já mencionado, a página analisada neste artigo tem, como público-alvo, professores e demais profissionais atuantes na área de educação, tendo em vista que seu próprio nome é direcionado para esse fim. Informa que busca promover, aos professores, desabafo sobre o mau comportamento dos alunos e troca de experiências acerca desses temas.

Essa página ressalta sua intolerância a eventuais desrespeitos ou atitudes inconvenientes por parte de seus integrantes, os quais são passíveis de exclusão. Entretanto, não salienta a importância de se respeitar a variação linguística, já que não menciona penalizar, também, casos de preconceito linguístico.

Dado o número frequente de postagens da página, os critérios para a seleção dos memes e comentários foram:

memes publicados no período de 01/10/2018 a 31/12/2018;

memes que incitavam comentários preconceituosos por, neles, já constar preconceito linguístico;

devido à grande quantidade de comentários em cada meme, foram analisados somente os dez primeiros.

A partir desses critérios, foram obtidos dez memes que estimulavam o preconceito

\footnotetext{
${ }^{5}$ Disponível em: <https://www.facebook.com/>. Acesso em: 30 set. 2019.
} 
linguístico ${ }^{6}$. Com o levantamento de dez comentários para cada meme, totalizamos 100 comentários, cuja análise é apresentada na seção subsequente.

\section{ANÁLISE DOS DADOS}

Dos 100 comentários analisados nesta pesquisa, 44 apresentam preconceito linguístico de forma mais evidente. Esse comportamento é manifestado de diferentes formas, como detalha esta seção.

Em um primeiro momento, verificamos que os participantes da página relacionam o preconceito linguístico presente no $m e m e^{7}$ às suas próprias realidades:

\section{(1) Sоииии еu.... Professora Cláudia rsrs ${ }^{8}$ \\ (2) [...] o que nossa sala precisa kkkkkkk}

(3) E quando eu vejo que essas pessoas estudaram comigo na faculdade, me desespero.

(4) [...] essa é a cara que eu faço, eu sei disso...

(5) O pior é qndo vc vê os alunos que vc deu aula escrevendo assim kkkkkkkkkké de chorar!

No comentário (5), explicita-se o fato de se tratar de um docente, que trata a escrita de alunos com escárnio. Não obstante, vale observar que o próprio comentário do docente, apesar de seu posicionamento, não segue a norma padrão, que prescreve "os alunos para quem você deu aula". Nesse caso, como estratégia de relativização, o escrevente fez uso da variante denominada relativa cortadora (BAGNO, 2002), em que a preposição ("para") regida pelo verbo é apagada.

Destacamos, também, comentários que evidenciam a noção equivocada de "erro" linguístico e, portanto, da existência de um Português "correto" ou "incorreto". A seguir, são mostrados esses comentários, sendo destacados em negrito os vocábulos que

\footnotetext{
${ }^{6}$ Esses memes estão presentes no Anexo.

${ }^{7}$ Os comentários foram transcritos mantendo o máximo possível sua forma original. Não são apresentados emojis, marcações de pessoas/páginas e quaisquer estruturas linguísticas que não sejam relevantes para a presente análise.

${ }^{8}$ Em um meme em que determinada "Profa. Cláudia" afirma ser proibida a língua do "emo", como em "coloquemo" (para "colocamos").

${ }^{9}$ Além das questões de abreviação e pontuação em textos de Internet, discussões que fogem do escopo deste trabalho.
} 
explicitam a noção de erro.

(6) [...] Como vamos ensinar nossos alunos com esses erros.

(7) E o pior que você não pode nem corrigir a pessoa, ela fica brava ainda.

(8) Errar e humano, mas não precisa ser tão humano assim!!!!!

(9) Não acho engraçado ficar desmerecendo pessoas simples que ñ escrevem

corretamente... Acho muito triste... Lamentável esse tipo de post...

(10) Não seria mais fácil ajuda-lo a corrigir? Claro que não, é mais fácil expor o ser humano, dar risada...é, bem mais fácil.

(11) Independente do erro, ela está trabalhando, poderia estar fazendo o que não presta, mas prefere ser uma pessoa de bem. Super parabéns.

(12) Vou lá!! Vai Que na matemática ele erra pra menos!!! kkkkkkk

(13) Tenho mais apreço aos que escrevem errado que aos que fazem errado.

(14) Achava que o bullying ou qualquer coisa parecida com isso era coisa de moleque, nao de pensadores. Ninguem escreve errado pq quer

(15) Eu adoro e os comentários como as pessoas são espertas, inteligentes e o pior como gostao de corrigir os erros dos outros como se elas não errassem né. (16) [...] mano se tu fala uma coisa dessa p mim, juro q te bloqueio, nem tento consertar

(17) Eu sei que isso errado na língua portuguesa, mas dia á dia não precisa ser correto, Nada melhor que uns erros deixam nossos dias alegres por sermos corrigidos e teimar que a gente fala do jeito que quer

(18) SOBRE ERROS DE PORTUGUESS NO FACEBOOK Erros de português acontecem até no meio universitário, no jornal e em revistas, até por jornalistas consagrados, isto não adianta, vamos valorizar o conteúdo dos textos e não se há erros de português. Ainda mais com essa péssima qualidade ensino de hoje. Até professores de português escrevem errado kkkkkkkkk [...] Melhor rir, que chorar. PORTANTO, ESCREVA CERTO OU ERRADO MAS ESCREVA, O QUE IMPORTA É SUA OPINIÃO QUE É MUITO IMPORTANTE.

(19) [...] se o mundo fala mortandela pq nao pode ser mortandela o corretoooo

Como explicitado anteriormente por Geraldi (1997), não existe "erro" linguístico. Conhecimento científico sobre Teoria da Variação e Mudança Linguística (LABOV, 2008 [1972]) não somente durante a formação no Ensino Superior do professor de língua, como também ao longo do Ensino Básico - evidentemente adaptado à idade, escolaridade e 
realidade dos alunos -, poderia diminuir ou até mesmo erradicar a concepção equivocada presente nos comentários (6-19).

No comentário 6, evidenciamos, novamente, o preconceito no comentário de um docente, que menciona "nossos alunos". Detectamos, assim, que até mesmo professores podem apresentar preconceito linguístico, não seguindo as orientações dos PCNs (BRASIL, 1998; 2000), que destacam sua tarefa de valorizar a multiplicidade linguística e combater o preconceito linguístico.

Outros comentários, inicialmente, opõem-se à crítica descrita no meme. Entretanto, continuam a defender a existência de um português "correto", admitindo que existem "erros" linguísticos. Nos comentários (15-16), os participantes reclamam do fato de não poderem "corrigir" ou "consertar" a pessoa que fala "errado" e atestam que, apesar de o "erro" ser uma característica humana, algumas pessoas fazem isso excessivamente comentário (8).

No comentário (17), retomamos a ideia destacada anteriormente por Calvet (2002) de que os próprios falantes da língua acreditam existir variantes de maior prestígio do que a utilizada por eles, concebendo, assim, que a variante que utilizam é estigmatizada ou inferior, caso denominado por Bagno (2017) como autoaversão.

O comentário (20), apresentado a seguir, não explicita a noção de “erro", pressuposta quando afirma talvez perdoar o autor de determinadas grafias não-convencionais presentes no anúncio de um bar.

(20) Será perdoado se o tira gosto for muito bom! [...]

Alguns participantes da página analisada tecem críticas a determinadas formas linguísticas, mostrando desconhecimento sobre fenômenos de variação linguística no PB, como ilustrado a seguir:

$$
\text { (21) Eu se... }
$$

(22) E ainda dizem: - Eu mim dei bem. Não sou professor. Rsrsrsrs

(23) [...] mim não é verbo, mim nao gosta de índio [...]

(24) NOSSA ENTÃO EU SEMPRE PASSEI VERGONHA AO FALAR IORGUTE

\section{KKKKK NEM O CORRETOR CORRIGE KKKKKKK}

(25) $[\ldots]$ (cardaço) tu lembra

(26) Mas no presente momento estou preferindo pessoas que falam "pobrema" aos que criam! 
(27) O pior é engolir algumas letras: *vo fala*, em vez de: vou falar (28) [...] "ah crush vc e lindo mais não escreve assim" "faiz" [...]

(29) Tá falta do ponhemo...

(30) "I só intende kemkizé " $k k k k k$

No comentário (21), critica-se o uso de "eu se" em casos como "eu se lembrei" (para "eu me lembrei") e "eu se formei" (para "eu me formei”). Segundo Ilari (2010, p. 322), há uma tendência ao uso de "se" a todas as pessoas do discurso, substituindo os pronomes me, te, nos e vos. "Se" é usado, por exemplo, para a primeira pessoa do singular, como em "eu se lavei” ("eu me lavei”), e para a primeira do plural, como em "nós não se conhece" ("nós não nos conhecemos").

Outra questão pronominal está presente no comentário (22), em que o participante critica o uso de "eu mim dei bem" (para "eu me dei bem"), sem considerar a variação pronominal dos pronomes oblíquos "me" e "mim". Ainda em relação a "mim", temos o comentário (23), que se relaciona à variação entre "eu" e "mim" na posição de sujeito, como em "isto é complicado para eu fazer" e "isto é complicado para mim fazer". Além de demonstrar preconceito linguístico, o participante demonstra discriminação racial ao explicitar, com tentativa de humor, que “mim não gosta de índio". Segundo Scherre (2005), o vocábulo "mim" costuma estar relacionado ao modo como as variantes linguísticas se dão nas comunidades indígenas, muitas vezes erroneamente concebidas como línguas primitivas.

Nos comentários seguintes, (24-25), os participantes caçoam das formas linguísticas "iorgute" (para "iogurte") e "cardaço" (para "cadarço"). Esses elementos linguísticos também correspondem a formas em variação, fenômeno presente em qualquer língua natural (LABOV, 2008 [1972]), como mencionado anteriormente. No caso, essas variantes sofrem o processo fonético-fonológico denominado metátese (HORA; TELLES, 2019), que consiste na "troca de posição de um segmento dentro de uma palavra" (SILVA, 2011, p. 152).

O comentarista seguinte (26) menciona a forma "pobrema", que representa o fenômeno variável denominado rotacismo, "relacionado com a realização fonética de um som rótico em substituição a um som lateral ou vice-versa" (SILVA, 2011, p. 197). De acordo com Bagno (2007; 2009b), o rotacismo diz respeito a um processo bastante antigo na história da língua portuguesa, visto que vários vocábulos com /r/ no encontro consonantal apresentavam /1/ em sua forma latina, como, por exemplo, "flaccu" (para "fraco"). Apesar disso, corresponde a um dos processos mais estigmatizados no PB 
contemporâneo.

No momento em que o comentarista seguinte (27) critica a forma "vo fala" (para "vou falar"), mostra ignorar os fenômenos variáveis de monotongação e apagamento de /R/ em coda silábica. O primeiro processo corresponde a um "fenômeno fonológico em que um ditongo passa a ser produzido como uma única vogal” (SILVA, 2011, p. 153), como em "vo" (para "vou") 10 . O segundo processo diz respeito ao apagamento do /R/, que ocorre, geralmente, em borda de palavra (SILVA, 2011), como em "falá" (para "falar") 11 . Esses apagamentos, devido à falta de conhecimento do participante da página, são interpretados por ele como o ato de "engolir algumas letras".

No comentário (28), temos "faiz" (para "faz"), correspondente a exemplo fornecido por Cagliari (1998) neste artigo: "rapaiz" (para "rapaz"). Deve ser retomada, portanto, a afirmação de que a escrita não corresponde a uma transcrição fonética da fala, o que faz com que surjam grafias que não seguem a convenção ortográfica (CAGLIARI, 1995; 1998).

Grafias não-convencionais como "faiz" e "rapaiz" estão relacionadas ao processo variável denominado ditongação ${ }^{12}$,

fenômeno fonológico de inserção de um glide após uma vogal ou transformação de um monotongo em um ditongo. No português brasileiro, a ditongação ocorre, em alguns dialetos, geralmente, em vogais tônicas em final de palavra, como, por exemplo, em português (SILVA, 2011, p. 93, grifo da autora).

Assim como no exemplo dado pela autora, $f a z$, monossílabo tônico, pode ser pronunciado como "fa[j]z", com a inserção do glide (ou semivogal). Notamos, também, que o próprio comentarista escreve "mais" quando usa a conjunção adversativa "mas", dando indícios do fenômeno e de sua relação com a escrita em sua própria variedade.

Quanto ao verbo "ponhemo", presente no comentário (29), referente ao meme "proibido língua do emo: botemo, larguemo, peguemo, busquemo", é perceptível o desconhecimento da variação em verbos de primeira pessoa do plural, mais especificamente

\footnotetext{
${ }^{10}$ Cf. Paiva (1996), Silva (1997), Amaral (2005), etc.

${ }^{11}$ Cf. Callou, Moraes e Leite (1998), Oushiro e Mendes (2014), Carmo e Taborda (no prelo), dentre outros.

${ }^{12}$ Cf. Leiria (2000), Rocha e Pereira (2007), Silva (2013), Uliano et al. (2014), Carlos e Carmo (2018), etc.
} 
em relação à troca da vogal temática/a/ por/e/, como em “coloquemos" (para “colocamos"), o que desfaz a ambiguidade das formas de presente ("nós colocamos") e pretérito do indicativo ("nós coloquemos") (PEREIRA, 2014; PEREIRA; MARGOTTI, 2018).

Por fim, no comentário (30), que afirma que "i só intende kemkizé”, verificamos, em "i" (para "e"), o fenômeno variável denominado alçamento vocálico, "que envolve a elevação da propriedade de altura da língua das vogais médias-altas [e] e [o] que se realizarão como as vogais altas [i] e [u]" (SILVA, 2011, p. 49) ${ }^{13}$. O alçamento vocálico explica, também, o exemplo apresentado neste artigo "leiti" (para "leite"), em contexto de vogal postônica final (ROBERTO, 2016). Para a vogal pretônica inicial, Bisol (1981) destaca o contexto em que essa vogal é seguida por /S/ ou /N/ em coda silábica, o que explica o dado "intende" (para "entende").

Por sua vez, em relação a "kemkizé” (para "quem quiser"), observamos, dentre outros elementos, a hipossegmentação, que ocorre "quando há a ausência do espaço em branco em locais previstos pela ortografia" (TENANI; PARANHOS, 2011, p. 480). Nesse caso, podemos retomar o segundo exemplo de Cagliari (1998) exposto neste artigo: "camanh" (para "com a mãe"), hipossegmentação que explicita a não relação biunívoca entre fala e escrita. De modo geral, retrata o desconhecimento da diferença entre o espaço em branco na escrita e o continuum do fluxo da fala, como em "porisso" (para "por isso") (ROBERTO, 2016).

Alguns comentários, por sua vez, associam grafias não-convencionais e variação linguística à falta de alfabetização e baixa escolaridade.

(31) Quando as pessoas não tem estudo, tudo bem. Mas quando é um Professor principalmente, nós temos por obrigação de elevar a linguagem. [...]

(32) Pior de tudo é ouvir do cidadão "EU NUM FISSO", quando perguntado se fez a lição de casa. Dói na alma.

(33) Gente é uma página de humor.... A maioria levam a ferro e fogo. Não gostou é só descurtir a página. Quem é semi analfabeto, está ofendido, estudem para melhorar. Vamos parar de demimimi, ser a vítima da sociedade . Precisamos evoluir [...] (34) Nem todo mundo tem a oportunidade de estudar. Melhore [...]. Tá feio. (35) Pôh o cara que escreveu tem talento só falta estudo (36) Era para ter indicado a ALFABETIZAÇÃO.

\footnotetext{
${ }^{13}$ Cf. Bisol (1981), Carmo (2013; 2014; 2018; 2019), Pereira (2010), Santos (2015), dentre muitos outros.
} 
(37) Muito difícil para ela. Eu indico o primeiro ano. Aprendizagem tem que começar com qualidade na base.

(38) Falar da má qualidade do ensino do país nesse tipo de post, chega beirar a ignorância. O ensino é péssimo, sim. [...]

(39) [...] e quantos com diplomas e sem nenhuma humildade.

Nos comentários (31-39) podemos constatar (i) a ideia equivocada de que a variação linguística depende de escolaridade; e (ii) o desconhecimento sobre relações entre grafias não-convencionais e variação linguística. Bagno (2009b) elenca, como um dos mitos linguísticos, "as pessoas sem instrução falam tudo errado". Defende, assim, que a escolarização não é fator primordial no que tange às diferenças linguísticas, pois existem fenômenos que explicam as variações existentes, já que, como citado, a variação linguística é estruturada, condicionada por fatores linguísticos e sociais (LABOV, 2008 [1972]). Entretanto, determinadas variantes são vistas como "erradas" por se tratarem de formas que ocorrem geralmente na língua(gem) de grupos minoritários, neste caso, os menos escolarizados.

Em (31), percebemos, mais uma vez, o preconceito linguístico no comentário de um professor, que explicita sua profissão e afirma ter a obrigação de "elevar a linguagem". Nesse sentido, demonstra acreditar na existência de uma linguagem inferior. De modo semelhante, o comentarista (37) dá indícios de exercer a mesma profissão, dizendo "doer na alma" ao se deparar com a forma "fisso" (para "fiz"). Ambos os professores demonstram, portanto, não seguir as orientações dos PCNs (BRASIL, 1998; 2000), apresentadas neste trabalho.

O próximo comentário tece uma ironia acerca da utilização de palavrões, apresentando-os de forma pejorativa e estigmatizando essa estrutura linguística:

(40) Fora os palavrões que esses eles dominam muito bem

O uso do palavrão pode ser classificado como variação diastrática, que ocorre em determinados grupos sociais para uma comunicação mais expressiva. Os palavrões podem ser usados sem carregar consigo uma conotação ofensiva, estando relacionados às comunidades de fala em que o falante está inserido (LEGROSKI, 2018). Assim, ao conceber o uso dos palavrões de forma pejorativa, destila-se o preconceito contra essa variante, julgando-a - equivocadamente - inferior às demais.

Constatamos, ainda, preconceito linguístico velado como posicionamento político: 
(41) Fruto, em grande parte, desses 16 anos que perdemos com administração do mal

$$
[\ldots]
$$

(42) Vamos precisar de, no mínimo, 10 anos de dedicação para reverter os absurdos dos últimos 30 anos!

Apesar de os comentários dos participantes serem voltados a aspectos políticos, ficam evidentes seus descontentamentos com as grafias não-convencionais presentes nos memes. Atrelam, dessa maneira, variação e ortografia a questões de políticas públicas governamentais.

A seguir, será evidenciada a ideia equivocada da língua como instrumento de ascensão social, outro mito apresentado por Bagno (2009b):

(43) Kkk...sempre me sinto privilegiada por conhecer e respeitar nossa lingua portuguesa...

(44) Realmente, é triste ver o nível do português das pessoas hoje em dia.

No exemplo (43), evidencia-se a ideia do comentarista de que o domínio da variante de prestígio é um privilégio. Entretanto, o domínio de uma variante que não condiz com a realidade da comunidade em que o indivíduo se insere não garantirá a ele a ascensão social. Ao contrário, essa variante classificada como privilegiada pode trazer problemas na comunicação dentro de sua comunidade de fala, pois, em alguns âmbitos sociais, a fala elitizada é desconhecida dos demais falantes, o que pode acarretar problemas na comunicação.

Da mesma forma, no comentário (44), a língua é concebida como "um mecanismo de poder" (SCHERRE, 2005, p. 23), tendo em vista que o comentarista não se insere nesse grupo. O comentário dissemina o preconceito linguístico ao defender que o nãodomínio da norma padrão e da ortografia é uma afronta à língua portuguesa, pressupondo que os usuários de variantes de menor prestígio têm um nível inferior comparado àqueles que dominam a norma padrão.

De modo geral, com base nos comentários de memes apresentados, constatamos que o preconceito linguístico está pautado, sobretudo, em uma concepção leiga promovida pelo ensino tradicional de gramática normativa: a existência de "certo"/“errado" na língua. Também está pautado no desconhecimento acerca de heterogeneidade linguística, fenômenos variáveis do PB e relações entre modalidades falada e escrita. 
Apesar de a página não conter objetivos científicos e, portanto, não podermos exigir, de seus participantes, conhecimento sobre Teoria da Variação e Mudança Linguística (2008 [1972]) e ensino de língua portuguesa segundo os PCNs (BRASIL, 1998; 2000), destacamos a relevância da propagação do conhecimento científico sobre língua(gem) na comunidade leiga, com o objetivo de erradicar ou, ao menos, reduzir o preconceito linguístico.

Essa propagação é possível por meio de uma formação sólida dos professores de língua portuguesa, em formação inicial e continuada. Apesar da ascensão de pesquisas em variação linguística no Brasil nas últimas décadas, não são todos os cursos de Licenciatura em Letras que apresentam disciplina específica sobre Sociolinguística em suas grades curriculares ${ }^{14}$. Ademais, defendemos o ensino de elementos (socio)linguísticos, como os processos variáveis recorrentes no $\mathrm{PB}$, nas aulas de língua portuguesa no Ensino Básico, promovendo, no aluno, a reflexão sobre sua língua e a observação de que a heterogeneidade linguística não é aleatória, mas, sim, estruturada e motivada por fatores não apenas sociais - como a escolaridade (cf. comentários 31-39) -, como também linguísticos (LABOV, 2008 [1972]).

Passamos, agora, às considerações finais.

\section{CONSIDERAÇÕES FINAIS}

Esta pesquisa analisou o preconceito linguístico em comentários de memes em uma página do Facebook voltada a docentes e profissionais da educação. Essa investigação possibilitou a confirmação de nossa hipótese inicial, referente à presença do preconceito linguístico, pautado no desconhecimento científico sobre língua(gem) e (socio)linguística por parte dos comentaristas.

Ainda que seu objetivo seja, muitas vezes, o humor - o qual também contribui para a naturalização do preconceito linguístico (RADTKE, 2017) -, os memes e seus comentários podem acarretar a propagação do preconceito nos meios sociais, depreciando as camadas socioeconômicas menos favorecidas pela forma como falam ou escrevem, e perpetuando, consequentemente, o preconceito linguístico.

Dada a importância dos processos variáveis para a constituição do $\mathrm{PB}$, bem como das relações que esses processos estabelecem com a modalidade escrita da língua, defendemos serem imprescindíveis a formação e a reflexão do profissional de Letras acerca

\footnotetext{
${ }^{14}$ Por exemplo, ausência observada, atualmente, nos cursos de Letras da UEPG, como pode ser observado em: <uepg.br/catalogo/cursos/2015.html>. Acesso em: 6 abr. 2020.
} 
da Teoria da Variação e Mudança Linguística (LABOV, 2008 [1972]) e do preconceito linguístico (BAGNO, 2002; 2007; 2009a; 2009b; 2017; CALVET, 2002; dentre outros).

Ressaltamos, também, a importância da análise de um método eficaz para o ensino-aprendizagem de língua portuguesa no Ensino Básico, que contemple os aspectos gramaticais conhecidos pelos alunos. A partir desse ponto, que se apresentem outras variantes e possibilidades gramaticais, aumentando seu repertório linguístico e promovendo a reflexão sobre o PB. Por meio do aprimoramento da competência comunicativa do aluno, amplia-se o combate ao preconceito linguístico, atendendo às orientações dos PCNs (BRASIL, 1998; 2000) para o ensino de língua portuguesa. 


\section{REFERÊNCIAS:}

AMARAL, M. P. Ditongos variáveis no sul do Brasil. Entre a transparência e a opacidade. Letras Hoje. Porto Alegre. v. 40, n. 3, p. 101-116, set. 2005.

BAGNO, M. Português ou Brasileiro? Um convite à pesquisa. $3^{\text {a }}$ ed. São Paulo: Parábola, 2002 .

BAGNO, M. Nada na língua é por acaso. 6a ed. São Paulo: Parábola, 2007.

BAGNO, M. Não é errado falar assim: em defesa do português brasileiro. São Paulo: Parábola, 2009a.

BAGNO, M. Preconceito linguístico: o que é, como se faz. 49ª ed. São Paulo: Loyola, $2009 b$.

BAGNO, M. Dicionário crítico de sociolinguística. São Paulo: Parábola, 2017.

BEZERRA, B. G.; PIMENTEL, R. L. Normativismo linguístico em redes sociais digitais: uma análise da fanpage Língua Portuguesa no Facebook. Trab. Ling. Aplic., Campinas, n (55.3): 731-755, set./dez. 2016.

BISOL, L. Harmonia vocálica: uma regra variável. 1981. Tese (Doutorado em Linguística) - Faculdade de Letras, Universidade Federal do Rio de Janeiro, Rio de Janeiro, 1981.

BRASIL. Parâmetros Curriculares Nacionais: $3^{\circ}$ e $4^{\circ}$ ciclos do Ensino Fundamental: Língua Portuguesa. Brasília: MEC/SEF, 1998.

BRASIL. Parâmetros Curriculares Nacionais: Ensino Médio: Língua Portuguesa. Brasília: 2000.

BRASIL. Base Nacional Comum Curricular. Brasília: MEC, 2018.

CAGLIARI, L. C. Alfabetização e Linguística. $8^{\mathrm{a}}$ ed. São Paulo: Scipione, 1995, p. 147181.

CAGLIARI, L. C. Alfabetizando sem o bá-bé-bi-bó-bu. São Paulo: Scipione, 1998.

CALlOU, D.; MORAES, J.; LEITE, Y. Apagamento do R Final no Dialeto Carioca: um Estudo em Tempo Aparente e em Tempo Real. Delta: Documentação de Estudos em Linguística Teórica e Aplicada, [s.1.], v. 14, p. 61-72, 1998.

CALVET, L. Sociolinguística: uma introdução crítica. Tradução de Marcos Marcionilo. 
São Paulo: Parábola, 2002.

CARLOS, V. G.; CARMO, M. C. Ditongação variável diante de /S/ em coda silábica na fronteira Brasil/Paraguai. Diadorim, Rio de Janeiro, v. 20, n. 2, p. 238-254, jul.-dez. 2018.

CARMO, M. C. As vogais médias pretônicas na variedade do interior paulista. 2013. 249f. Tese (Doutorado em Estudos Linguísticos) - Instituto de Biociências, Letras e Ciências Exatas, Universidade Estadual Paulista, São José do Rio Preto, 2013.

CARMO, M. C. As vogais médias pretônicas no noroeste paulista: comparação com outras variedades do Português Brasileiro. Revista Estudos Linguísticos. v. 43, n. 1, p. 33-47, jan./abr. 2014.

CARMO, M. C. Variação linguística das vogais médias pretônicas em contexto medial no noroeste paulista. Uniletras. Ponta Grossa, v. 40, n. 2, p. 222-240, jul./dez. 2018.

CARMO, M. C. Alçamento vocálico das vogais médias pretônicas iniciais na variedade do noroeste paulista. Revista Estudos Linguísticos, v. 48, n. 2, p. 800-821, jul. 2019.

CARMO, M. C.; TABORDA, I. R. Apagamento de /R/ em coda silábica na variedade do interior paulista. Letras Escreve. No prelo.

CELANI, M. A. A. Questões de ética na pesquisa em Linguística Aplicada. Linguagem e ensino. Pelotas: Pontifícia Universidade Católica de São Paulo: jan./jun. 2005; v. 8, n. 1, p. 108-122.

DAWKINS, R. O Gene Egoísta. Tradução de Rejane Rubino. São Paulo: Companhia das Letras, 2007.

GERALDI, W. O texto na sala de aula. São Paulo: Ática, 1997.

HORA, D.; TELlES, S. Metátese. In: TELLES, C. M. et al. História do português brasileiro: mudança fônica do português brasileiro. São Paulo: Contexto, 2019, p. 160177.

ILARI, R. Os pronomes do português brasileiro, algumas comparações. Estudos linguísticos. São Paulo, 39 (1), p. 314-330, abr./maio. 2010.

LABOV, W. Padrões sociolinguísticos. Tradução de Marcos Bagno, Maria Marta Pereira Scherre e Caroline Rodrigues Cardoso. São Paulo: Parábola, 2008 [1972].

LEIRIA, L. L. A ditongação variável em sílabas tônicas finais travadas por/S/. Organon. 
v. 14. n. 28-29. Porto Alegre: UFRGS, p. 133-141, 2000.

LEGROSKI, M. C. Escala de ofensividade: quão ofensiva essa expressão é? Estudos Linguísticos. São Paulo, 47 (1), p. 169-180, 2018.

OUSHIRO, L.; MENDES, R. B. O apagamento de (-r) em coda nos limites da variação. Veredas. Juiz de Fora. v. 18. n. 2. p. 251-266. 2014.

PAIVA, M. C. A. Supressão das semivogais nos ditongos decrescentes. In: SILVA, G. M. O.; SCHERRE, M. M. P. (Org.). Padrões sociolinguísticos: análise de fenômenos variáveis do português falado na cidade do Rio de Janeiro. Rio de Janeiro: Tempo Brasileiro, 1996, p. 217-236.

PEREIRA, I. Cuidamo(s) e cuidemo(s): a variação morfêmica na $\mathrm{P} 4$ em verbos regulares de $1^{\text {a }}$ conjugação. Work. Pap. Linguíst., 15 (2): 49-71, Florianópolis, ago./dez., 2014.

PEREIRA, R. C. M. Uma análise variacionista das vogais médias pretônicas. João Pessoa: Editora Universitária da UFPB, 2010.

PEREIRA, I.; MARGOTTI, F. W. Sobre onde nós fiquemo: mapeamento diatópico de um traço linguístico rural brasileiro. Web-Revista SOCIODIALETO, v. 8, n. 24, mar. 2018.

PINTO, A. M. G.; JUNQUEIRA, L. A. P. Relações de poder em uma rede do terceiro setor: um estudo de caso. Revista de Administração Pública. Rio de Janeiro 43 (5), p. 1091-1116, set./out. 2009.

RADTKE, N. G. "Sejemenas": um estudo sobre o preconceito linguístico no Facebook. 2017. 103f. Dissertação (Mestrado em Letras) - Universidade Católica de Pelotas, Pelotas, 2017.

ROBERTO, M. Fonologia, fonética e ensino: guia introdutório. São Paulo: Parábola, 2016.

ROCHA, P. G.; PEREIRA, R. A. O processo de ditongação sob a perspectiva da fonologia gerativa: aspectos sob variação linguística. Revista Língua e Literatura. v. 9, n. 13, p. 6992, 2007.

ROMANO, V. P.; PEREIRA, B. C. E. (In)tolerância e preconceito linguístico no ciberespaço: reflexões acerca dos comentários de usuários. Entrepalavras, Fortaleza, v. 7 , p. 331-350, ago./dez. 2017. 
SANTOS, A. P. Variação e mudança no vocalismo postônico medial em Português. 2015. 228f. Tese (Doutorado em Letras Vernáculas) - Faculdade de Letras, Universidade Federal do Rio de Janeiro, Rio de Janeiro, 2015.

SCHERRE, M. M. P. Doa-se lindos filhotes de poodle: variação linguística, mídia e preconceito. São Paulo: Parábola, 2005.

SILVA, A. R. Contribuições da Geolinguística nordestina ao estudo de um fato em variação: a ditongação diante de /S/. Entrepalavras. Fortaleza. Ano 3, v. 3, n. 1, p. 230250, jan./jul. 2013.

SILVA, F. S. O processo de monotongação em João Pessoa. 1997. 120f. Dissertação (Mestrado em Letras) - Universidade Federal da Paraíba, João Pessoa, 1997.

SILVA, T. C. Dicionário de fonética e fonologia. São Paulo: Contexto, 2011.

TARALLO, F. A pesquisa sociolinguística. $7^{\text {a }}$ ed. São Paulo: Ática, 2003.

TENANI, L.E.; PARANHOS, F. C.Análise prosódica de Segmentações não-convencionais de palavras em textos do sexto ano do Ensino Fundamental. Filol. linguíst. port., n. 13 (2), p. 477-504, 2011.

ULIANO, C. G.; CARVALHO, M. F. S.; DEGANI, M. C.; BROD, L. E. M. A ditongação das sílabas tônicas finais travadas nos falares blumenauense e porto-alegrense: uma análise preliminar. Revista Acadêmica de Letras Português - UOX, n. 2, p. 94-104, 2014. 


\section{ANEXO' $^{15}$}

Figura 1: Meme $1^{16}$

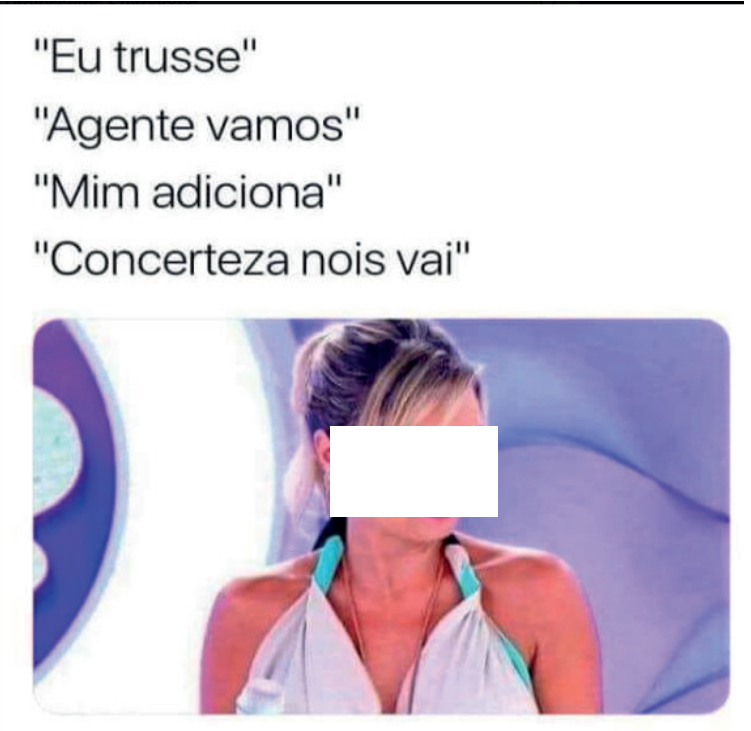

Figura 2: $\mathrm{Meme}^{2}$

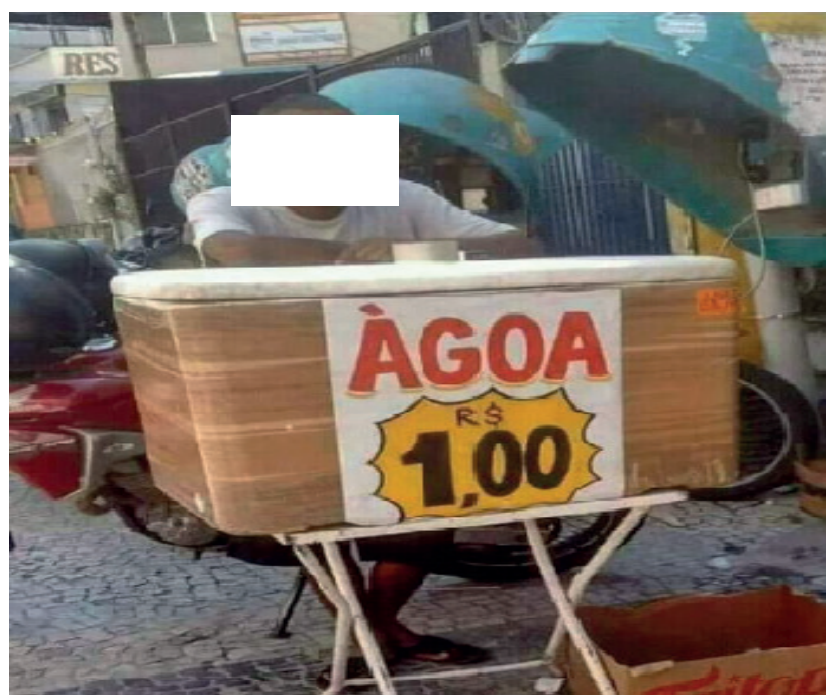

${ }^{15}$ Como fonte de todos os memes apresentados, temos: $<$ https://www.facebook.com $>$. Acesso em: 15 mar. 2019.

${ }^{16}$ Por questões éticas, os memes foram alterados pelas autoras deste trabalho, que ocultaram (i) identidades das pessoas; e (ii) nomes de páginas e de estabelecimentos comerciais. 


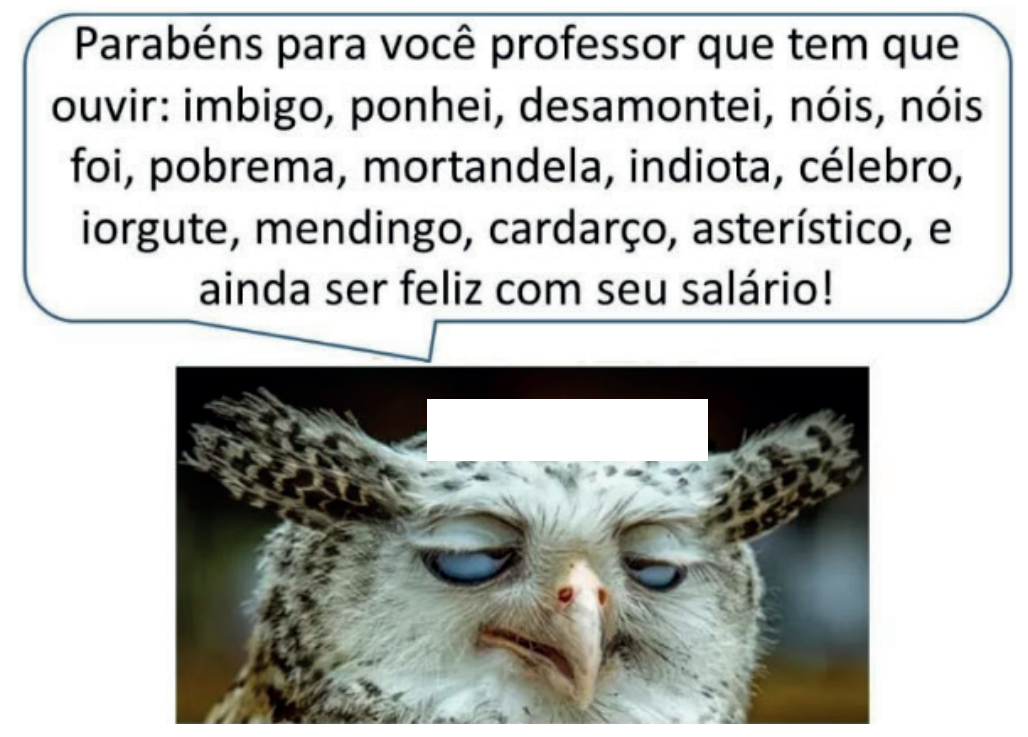

Figura 4: Meme 4

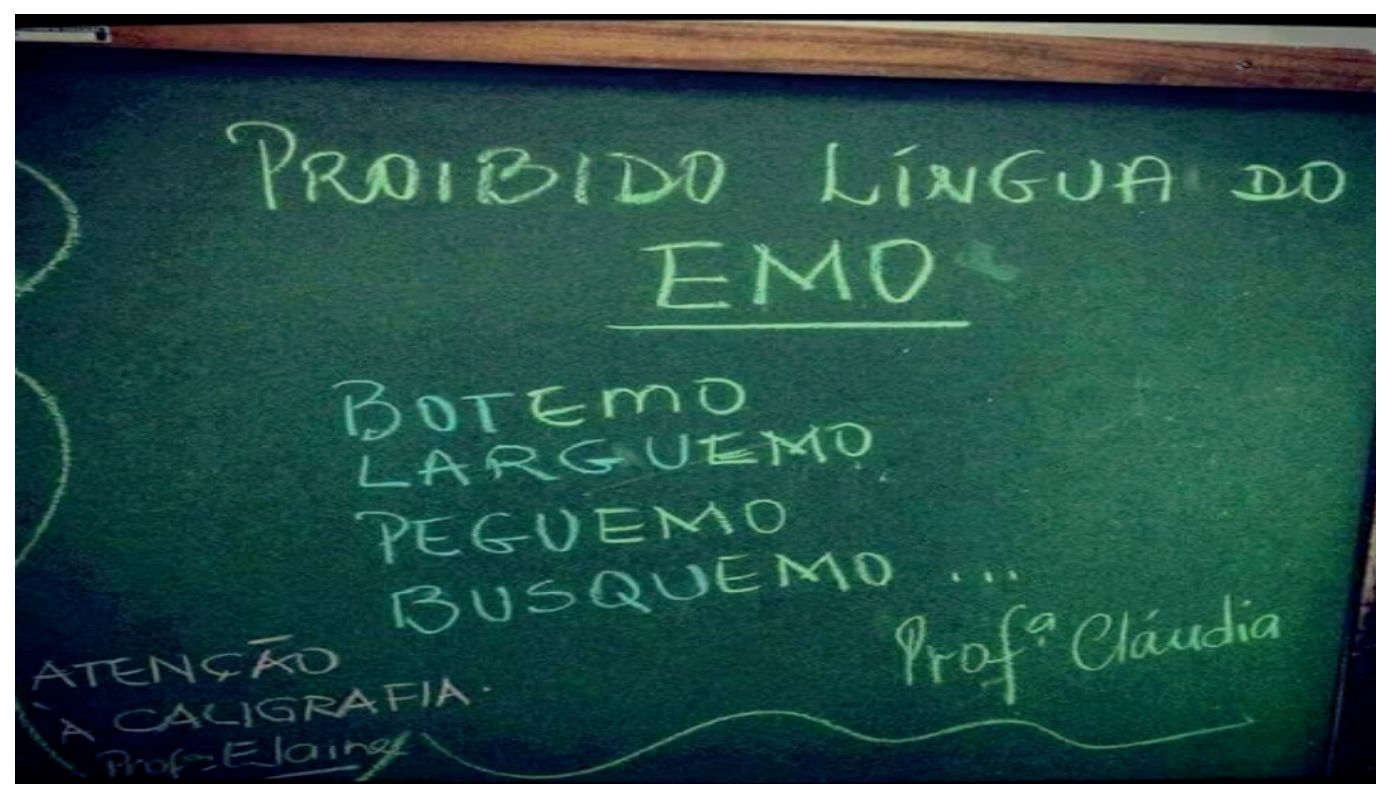




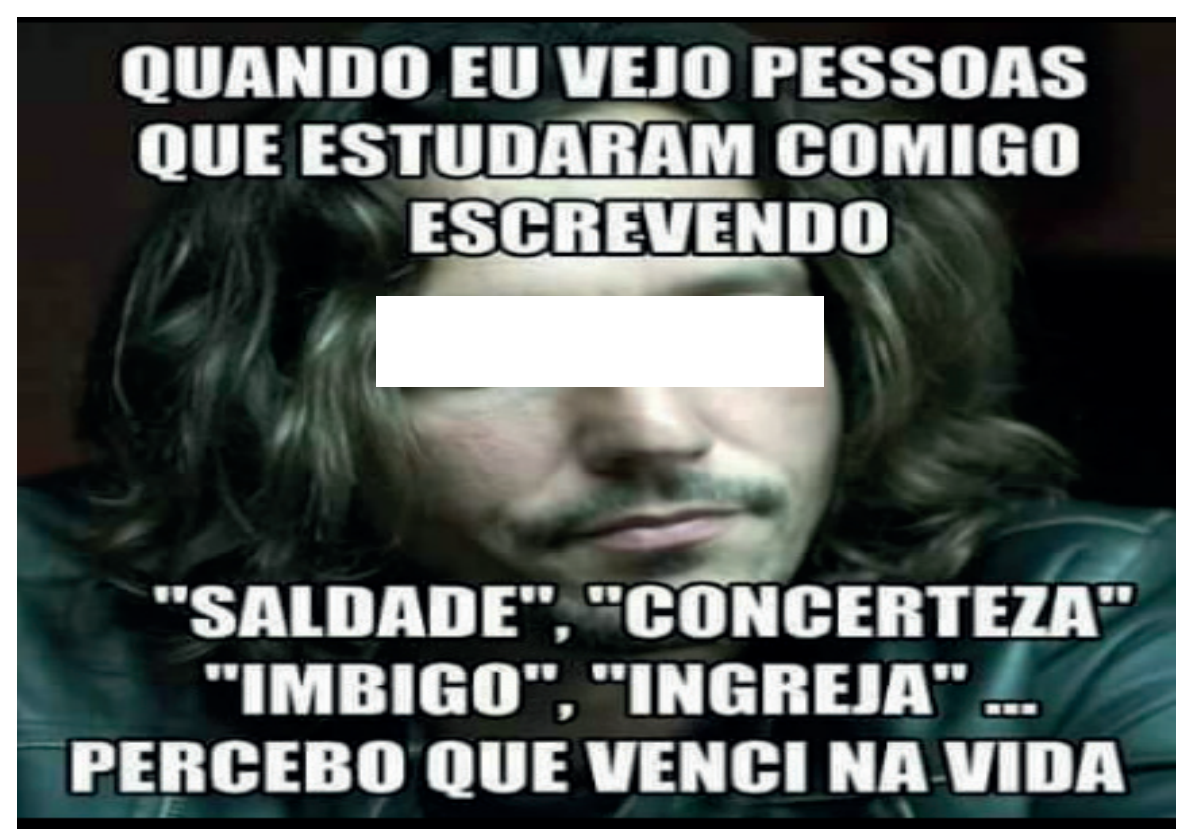

Figura 6: Meme 6

saindo levando minha filha pro pé de atra

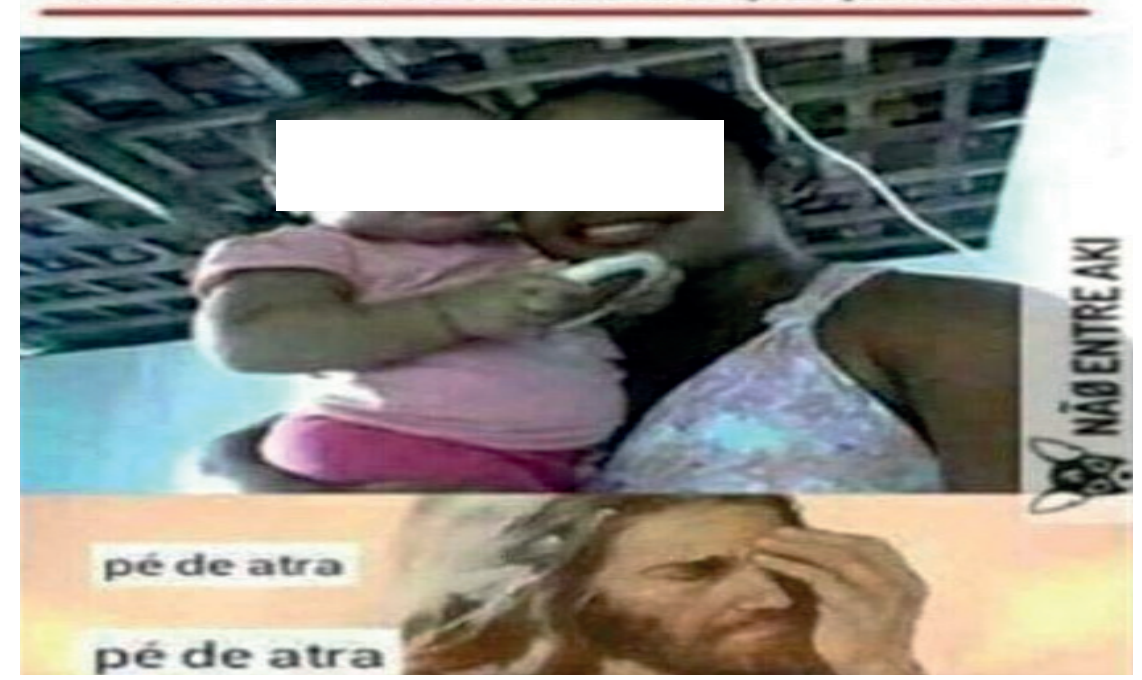


Figura 7: Meme 7

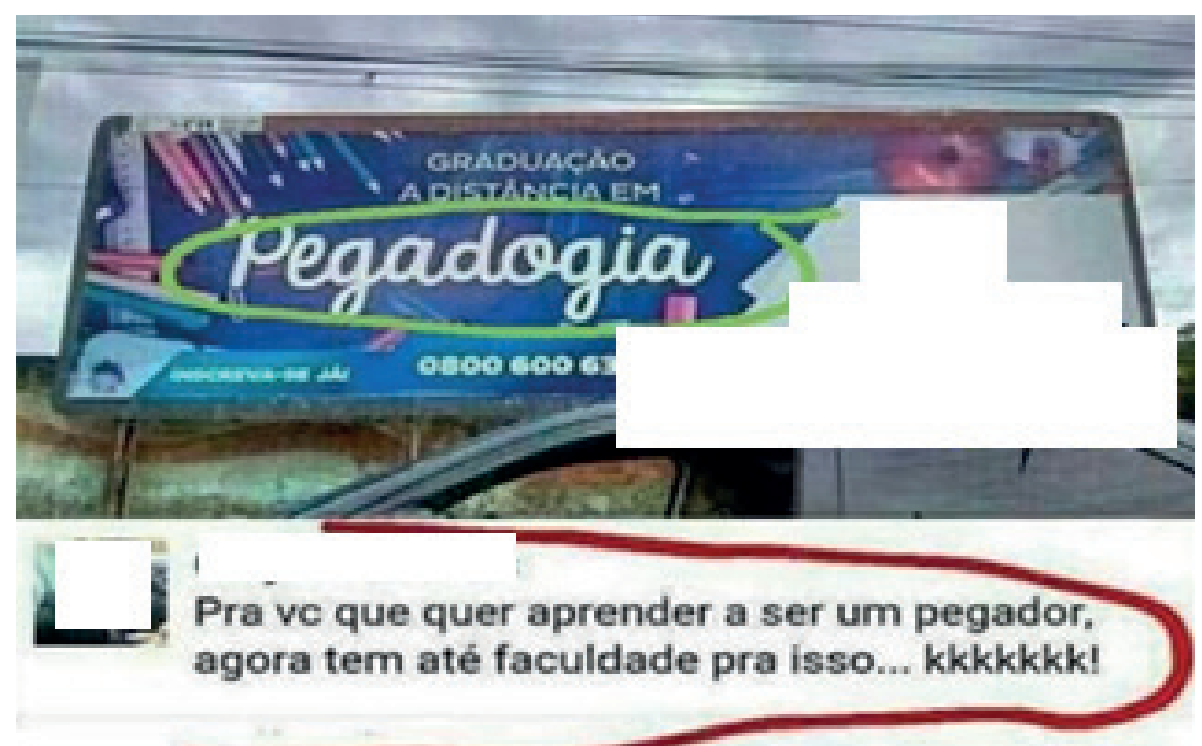

Figura 8: Meme 8

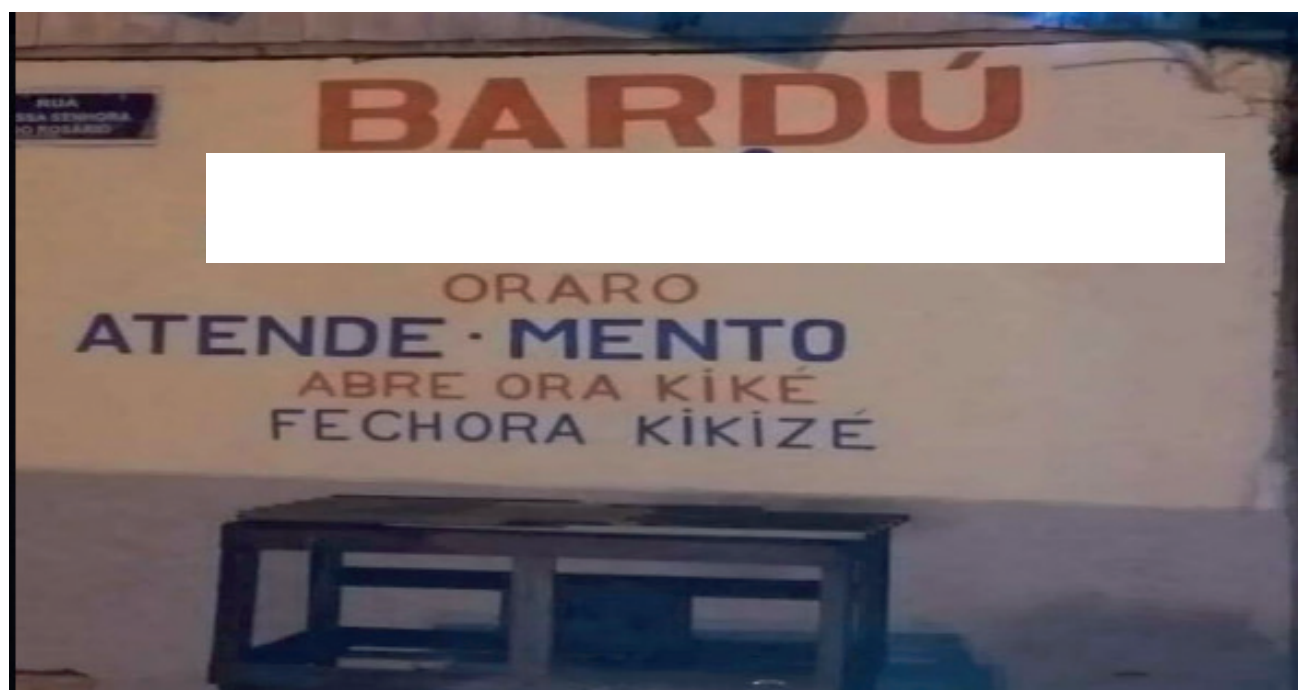




\section{Partiu praia !! já falei!! Não "mim" inveje, trabalhe!!}

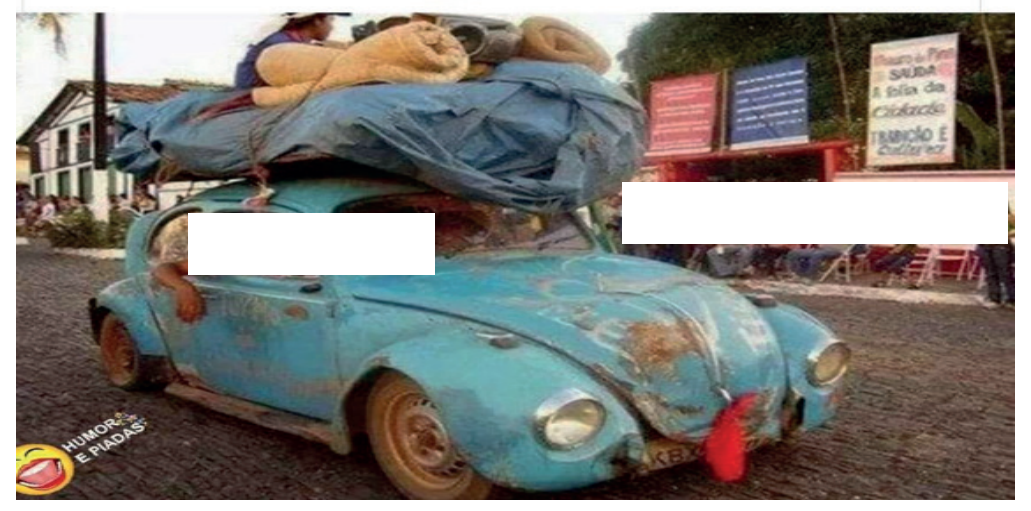

Figura 10: Meme 10

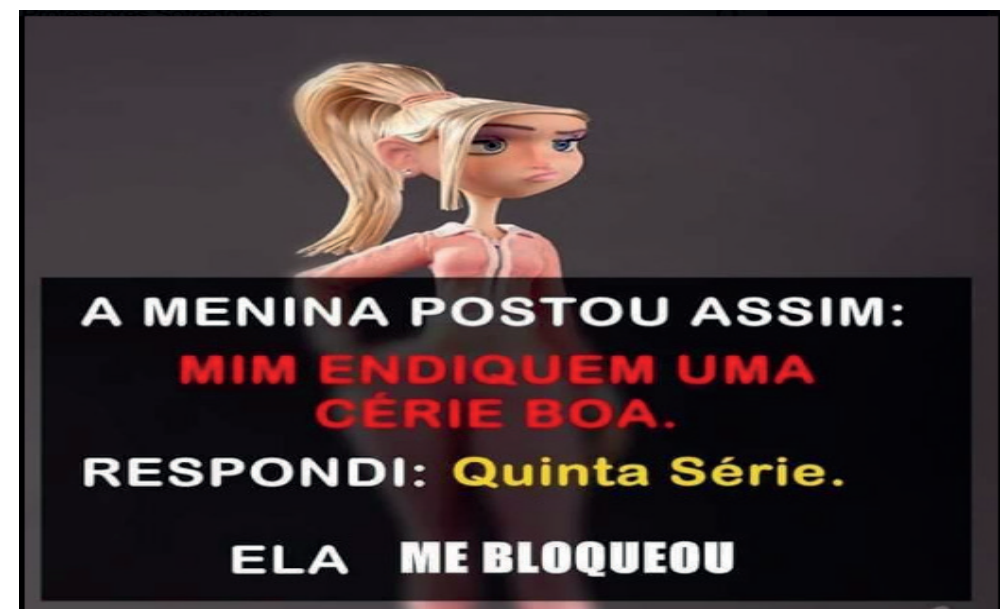

Recebido em: 30 set. 2019

Aceito em: 20 abr. 2020 